\title{
Social Innovation 2015: Pathways to Social Change Research, Policies and Practices in European and Global Perspectives
}

\section{Beč, 18. - 19. studenog 2015. godine}

Kroz potragu za novim načinima borbe s najizazovnijim socijalnim problemima razvija se koncept socijalnih inovacija. Socijalne se inovacije javljaju kao naznake novog promišljanja socijalnih politika kako bi se osigurali društveni i ekološki održiv rast, bolja radna mjesta i veća kvaliteta života. Socijalne inovacije socijalne su kroz ciljeve i sredstva - nove ideje (proizvodi, usluge i modeli) koje istovremeno odgovaraju na socijalne potrebe (učinkovitije nego alternative) i stvaraju nove društvene odnose ili suradnje. Inovacije su dobre ne samo za društvo već povećavaju i sposobnosti pojedinaca za djelovanje (BEPA, 2010.) ${ }^{1}$. Glavni je cilj socijalnih inovacija pronaći rješenja za socijalne probleme: prepoznavanjem i pružanjem novih usluga koje poboljšavaju kvalitetu života pojedinaca i zajednica, identificiranjem i provođenjem procesa integracije na tržištu rada, novim sposobnostima, novim radnim mjestima i novim oblicima sudjelovanja, kao različitim elementima koji pridonose poboljšanju položaja pojedinaca (Pol i Ville, 2007.:880)².

Europska unija u svojim politikama stavlja fokus na socijalne inovacije kroz više različitih strategija, programa i inicijativa. Polazi se od pretpostavke kako socijalne inovacije mogu dijelom premostiti financijske probleme lokalnih socijalnih programa i ojačati socijalnu koheziju. Kroz hrvatsko iskustvo poimanja i razvoja socijalnih inovacija (Bežovan, Matančević i Baturina, 2014.a, 2014.b)3 uočava se kako su socijalne inovacije zapostavljena tema, koncept nepoznat u sačinjavanju i provedbi programa socijalne politike. Centralizirana i paternalistička država pretjerano regulira razvoj usluga i socijalnih programa, te koncept najbolje prakse nije prepoznat kao instrument politike. Razvidna je potreba za povećanjem utjecaja dionika prilikom pripreme, donošenja i provedbe socijalnih programa, kao i otvaranje prostora za

1 BEPA (2010). Empowering people, driving change. Social innovation in European union. http://ec.europa.eu/bepa/pdf/publications_pdf/social_innovation.pdf

2 Pol, E. i Ville, S. (2009). Social innovation: Buzz word or enduring term? The Journal of Socio-Economics, 38:878-885.

3 Bežovan, G., Matančević, J., Baturina, D. (2014a). Zagreb, u: Evers, A., Ewert, B., Brandsen, T. (Ur.). Social innovations for social cohesion: transnational patterns and approaches from 20 European cities. Liege: EMES. i Bežovan, G., Matančević, J., Baturina, D. (2014b) Varaždin, u: Evers, A., Ewert, B., Brandsen, T. (Ur.). Social innovations for social cohesion: transnational patterns and approaches from 20 European cities. Liege: EMES. 
raspravu o relevantnim izazovima za razvoj socijalne politike, među kojima su svakako i socijalne inovacije. Ovaj prikaz konferencije poziv je i poticaj za povećanje javnog interesa o toj temi.

Konferencija Pathways to social change organizirana je od dvaju projekata Okvirnog programa 7 (FP7) EU-a: Social innovation - Driving force of social change $\left(\right.$ SI-DRIVE) ${ }^{4}$ i Transformative social innovation theory (TRANSIT) 5 te Net4Society ${ }^{6}$, mreže nacionalnih kontaktnih točaka u programu Obzor 2020. U organizaciji konferencije surađivali su s još dvama projektima FP7: Creating economic space for social innovation - (CRESSI $)^{7}$ i Boosting the impact of social innovation in Europe through economic underpinnings (SIMPACT) ${ }^{8}$.

Osim glavnog izlaganja konferencija je imala čak 22 tematske sesije, pokrivajući mnogobrojne aspekte socijalnih inovacija. Uz to su organizirane i posjete konkretnim socijalnim inovacijama te posebne sesije za daljnje povezivanje i mogućnosti suradnje.

Prvi je dan započeo dvama glavnim izlaganjima: Social innovation and new pathways to social change - first insights from the global mapping, nakon kojeg je slijedilo izlaganje Transformative social innovation: Empirical \& theoretical insight. Izlaganja su predstavila socijalne inovacije kao nove putove društvenih promjena i dala uvide u spoznaje tekućih projekata FP7, SI DRIVE i TRANSIT.

Nakon toga slijedilo je sedam paralelnih jutarnjih sesija. ${ }^{9}$ Sesija Life cycles of social innovations uz kratke je primjere slučajeva identificirala zajedničke ili posebne odrednice koje utječu na životni tijek socijalnih inovacija. Druga je sesija bila Empowerment for vulnerable people through digital social innovation. Glavna su pitanja sesije bila koliko socijalne inovacije za ranjive skupine mogu biti potpomognute

${ }^{4}$ Glavno je poslanje projekta integrirati teorije i metodologije kako bi se unaprijedilo razumijevanje socijalnih inovacija. Putem mapiranja socijalnih inovacija, uzimajući u obzir posebnosti različitih konteksta, žele izgraditi novu paradigmu inovacija. Više informacija o projektu: http://www.simpact-project.eu/

5 http://www.transitsocialinnovation.eu/ TRANSIT za cilj ima razviti teoriju o procesu kroz koji socijalne inovacije pridonose transformativnoj promjeni.

6 http://www.net4society.eu/

7 CRESSI istražuje ekonomsku podlogu socijalnih inovacija s posebnim naglaskom na tome kako politika i praksa mogu poboljšati živote marginaliziranih i obespravljenih građana. Ako želite saznati više: http://www.sbs.ox.ac.uk/faculty-research/research-projects/cressi

8 Projekt SIMPACT sustavno istražuje ekonomske temelje socijalnih inovacija kako bi osigurao dinamični okvir za djelovanje na razini pojedinaca, organizacija i mreža. Više informacija o projektu: http://www.simpact-project.eu/

9 Uslijed broja sesija i preklapanja tek ih je manji dio bilo moguće pokriti sudjelovanjem. Kraće informacije o temama i svrhama ostalih sesija dajemo na temelju programa, popratnih dokumenata i dostupnih izlaganja. 
digitalnim sredstvima i koji su aspekti ranjivosti posebno otvoreni za digitalne socijalne inovacije. Social innovation ecosystems bila je još jedna od jutarnjih sesija. Naglasila je manjak kontinuirane i sustavne analize socijalnih inovacija, njihovih teorija, karakteristika i utjecaja, kao i odnosa između socijalnih inovacija i promjena u društvu. Sesija Beyond 'scaling up': spatial perspectives on social innovation razmatrala je širu perspektivu o važnosti mjesta i prostora za socijalne inovacije, posebno se fokusirajući na društvene prakse i načine interakcije ljudi i mjesta. Na sesiji Innovating research? Approaches and methods to research social innovation kritički se sagledalo različite pristupe i metode za proučavanje socijalnih inovacija. Pitanja su bila koji su izazovi tekućih pristupa i treba li inovirati način na koji se istražuju socijalne inovacije. Analiziranje različitih teorija promjena i mehanizama kojima se učinkovita društvena transformacija može postići bila je tema sesije Theories of change in sustainability transitions: the role of agency. Sesija Service design, public sector and social innovation istraživala je mogu li se procesi participativnog dizajna primijeniti za poticanje inovacija u javnom sektoru te kako prototipovi i manji eksperimenti mogu biti pretvoreni u šire prakse.

U pauzi je slijedio zajednički ručak u hotelu „Magdas“. Hotel zapošljava izbjeglice i priređuje grupne večere gdje građani Beča susreću tražitelje azila.

Popodnevna su događanja isto tako započela sa sedam paralelnih sesija. Kako socijalne inovacije nemaju stabilizirani okvir (pojmova i metodologija), postavlja se pitanje što su prikladne mjere za procjenu utjecaja socijalnih inovacija. Sesija Social innovation impact assessment: Approaches, methods and tools naglasila je težinu tog pitanja imajući u vidu višedimenzionalnost koncepta i višedisciplinarni opseg njihovog utjecaja. Na sesiji Social innovation \& workplace innovation istraživalo se kako se inovacije na radnom mjestu i socijalne inovacije mogu međusobno inspirirati te kako na radnom mjestu možemo osmisliti inovacije koje bi unaprijedile sposobnosti radnika i organizacije. Potičući razumijevanje ekonomskih dimenzija socijalnih inovacija, sesija The economic dimension of social innovation naglasila je dilemu o djelotvornosti rješavanja socijalnih problema, učinkovitosti raspodjele resursa te balansiranja troškova i prihoda. Participation, motivation and responsibility predstavila je rezultate istraživačkih projekata ZSI-SI-ja ${ }^{10}$ (SOCIENTIZE ${ }^{11}$, SI DRIVE i CASI project ${ }^{12}$ ), naglašavajući aspekte participacije i strukture vladavine koji motiviraju uključivanje u socijalne inovacije. Interaktivna sesija Narrative of change and social innovation omogućila je dijeljenje i uspoređivanje empirijskih zapažanja o diskursima o socijalnima inovacijama i različitim narativima promjene koje ljudi koriste u radu s njima. Socijalne inovacije uključuju međuljudske odnose. Stoga se na sesiji Interpersonal relational qualities of social innovations: perspectives for the service sector and public policies raspravljalo o tome koliko one mogu biti važan izvor novog znanja o inovativnoj arhitekturi usluga i interakcija na temelju suradnje.

10 Centar za socijalne inovacije: https://www.zsi.at/en/home

11 O projektu možete saznati na: http://www.socientize.eu/

12

Za više informacija: http://www.casi2020.eu/ 
Radionica New directions in theory on social innovation and (transformative) social change bila je prilika za razmjenu znanja i raspravu o napretku teorije o razvoju socijalnih inovacija i transformativne društvene promjene.

Nakon popodnevnih sesija uslijedila je plenarna rasprava Participation and beyond: Co-production and urban transformation. Urbana transformacija odnosi se na svjetsku urbanizaciju i specifične procese lokalne transformacije u gradovima, koje su pokretane socijalnim inovacijama. Plenarna je sesija za cilj imala stvoriti opipljiv ishod pokretanja suradničke mreže gradova socijalnih inovacija, kojoj bi bio izazov pridružiti i neki od naših gradova.

Drugi je dan počeo debatom International policy debate, na kojoj se raspravljalo o kontekstualnosti perspektiva socijalnih inovacija na različitim kontinentima. Dovela se u pitanje mogućnost jednoobraznog definiranja socijalnih inovacija i zaključilo kako se više treba oslanjati na uvide koje daju brojne inicijative u praksi.

Debatu su, kao i prvog dana, slijedile tematske sesije. Systemic play to change the game bila je sesija na kojoj su sudionici stekli dublje razumijevanje kontekstualnog značenja i temeljne dinamike transformacije socijalnih inovacija i sustavnih promjena. Facilitation skills in social innovation bila je radionica usmjerena na unapređivanje vještina vezanih za procese koprodukcije i razvoj znanja o socijalnim inovacijama. Responsible research and innovation - quality criteria and evaluation standards usmjerila se na predstavljanje prvog kataloga kriterija kvalitete koji je osnova za alat refleksije. U radionici Responsible research and innovation primijenio se nacrt alata za procjenu istraživačke i inovacijske aktivnosti. Sudionici sesije Beyond tendering: public policy as an active enabler of social innovation sagledali su pojavu novih oblika proizvodnje i provedbe politika te procijenili buduće mogućnosti. Radionica Social innovation methodologies for community intervention fokusirala se na stvaranje prototipa socijalnih projekata, naglašavajući aspekte definiranja društvenog problema i razvijanja učinkovitog rješenja u kratkom vremenskom razdoblju. Socijalne inovacije karakteriziraju intrinzične suprotnosti kao i kontekstualni uvjeti, stoga je sesija Rethinking business models for social innovation razmatrala kako te suprotnosti i uvjeti dovode do stvaranja složenih poslovnih modela, koji se razlikuju od onih komercijalnih poduzeća. Sesija naziva Trojan horses in social innovation: Dealing with disempowerment, unintended consequences and dilemmas osvrnula se na važno pitanje o mogućim negativnim učincima socijalnih inovacija, o tome kako se mogu prevladati te koje su implikacije za teoriju i praksu socijalnih inovacija. Što socijalne inovacije razlikuje i koje su njihove specifičnosti u Srednjoj i Istočnoj Europi bila je tema sesije Central and eastern European features of social innovation. Raspravljalo se o kontekstualnim povijesnim, kulturnim, političkim i ekonomskim elementima koji su oblikovali socijalne inovacije u Srednjoj i Istočnoj Europi.

Drugi je posjet bio primjeru socijalnog stanovanja iz razdoblja "crvenog Beča", Goethe-Hof - From social innovation to social transformation. Socijalno stanovanje, uz ključnu ulogu grada Beča, ekstenzivno je razvijano te je imalo dugoročan antisegregaciji učinak. U isto se vrijeme odvijao posjet projektu socijalnog stanovanja VinziRast-mittendrin, gdje beskućnici i studenti žive, rade i uče zajedno pod jednim 
krovom. Projekt pokreće uvjerenje da život u zajednici može biti podrška i liječiti psihološke rane.

Na samom kraju programa održala su se dva događanja. Sesija Net4Society B2B fokusirala se na buduću suradnju u istraživanju i uključivanju korisnika. Net4Society međunarodna je mreža nacionalnih kontaktnih točaka za Društveni izazov 6 („Europa u svijetu koji se mijenja: uključiva, inovativna i refleksivna društva“) u programu Obzor 2020. Isto tako predstavila se European school of social innovation, koja za cilj ima jačanje istraživanja, obrazovanja, promoviranje mladih istraživača te prijenos znanja o socijalnim inovacijama.

Konferencija je bila ključan događaj na temu socijalnih inovacija i povezala je znanstvenike s kreatorima politike i praktičarima. Usmjerila se na trenutne dosege znanja u osmišljavanju i izradi socijalnih inovacija. Sagledani su resursi, sredstva i faktori koji čine procese socijalne inovacije uspješnima, kao i međunarodna praksa njihovih politika i istraživanja.

Velike nade koje se polažu u socijalne inovacije u pogledu malih pokreta i lokalnih aktivnosti govore o stalnoj potrebi za utopijama u vremenima matica politike koje građanima govore da ne postoji alternativa zamrznutim širim sustavima socijalne politike (Evers i Evert, 2012.) ${ }^{13}$ i ekonomije. Ključno je postojanje prostora da se čini nešto drugačije. Najuspješnije socijalne inovacije grade se u optimalnom vremenu i kapitaliziraju više putanja socijalne, ekonomske i političke transformacije, koja je u društvu već u tijeku. Ovaj je prikaz time dijelom i poziv akademskoj zajednici, praktičarima, dionicima iz civilnog društva, ali i kreatorima politika za razmatranje i istraživanje teme socijalnih inovacija.

Danijel Baturina Pravni fakultet Sveučilišta u Zagrebu, Studijski centar socijalnog rada

13 Evers, A., Ewert, B. (2012). Social Innovations for Social Cohesion. On concepts and first findings of a cross-country study. Edinburgh: 10th Annual ESPAnet conference paper. 